politica, 35. årg. nr. 3 2003, 303-318

Sune Lægaard

\title{
Liberal nationalisme og begrebet om nationen ${ }^{1}$
}

Liberal nationalisme er synspunktet at 1) en fælles national identitet er en forudsætning for social solidaritet, og 2) statslig sikring af en sådan fælles identitet er forenelig med liberalisme. Nationsbegrebet og to argumenter for den første påstand diskuteres med udgangspunkt i David Millers skrifter, hvorpå synspunktet kritiseres for at stille potentielt modsatrettede krav til nationale identiteter.

Liberal nationalisme er en klasse af synspunkter inden for normativ politisk teori der siden 1990'erne har fået større og større opmærksomhed. Dette af flere grunde:

1. De lader til at kunne begrunde visse former for nationalisme uden uacceptable konsekvenser i form af intolerance og krænkelse af individers rettigheder.

2. De svarer på en af de kommunitaristiske indvendinger mod liberalisme, nemlig problemet om social enhed og stabilitet.

3. De giver en teoretisk formulering af og potentiel begrundelse for visse opfattelser i den aktuelle politiske debat, for eksempel at immigration må begrænses og at indvandrere skal integreres i dansk kultur, jf. regeringens udlændingelov.

I det følgende fremstilles og diskuteres den formulering af liberal nationalisme der findes hos David Miller (1995, 2000, 1988, 1988-89). ${ }^{2}$ Miller er valgt fordi han er den mest fremtrædende repræsentant for liberal nationalisme inden for politisk teori, fordi han formulerer de centrale argumenter på en måde der indfanger en del af den aktuelle politiske debat, og fordi han samtidig eksemplificerer et generelt problem for liberal nationalisme. Efter præcisering af hvad der generelt forstås ved liberal nationalisme, fokuseres på to af Millers argumenter der svarer til denne karakteristik. Efter en redegørelse for argumenterne og en uddybning af hvilket begreb om nationen Miller opererer med i dem, diskuteres om Miller kan leve op til ambitionerne i liberal nationalisme, og i forbindelse hermed skitseres et generelt problem for alle former for liberal nationalisme.

\section{Liberal nationalisme}

At synspunktet er liberalt, vil overordnet sige at alle personer betragtes som bærere af samme individuelle rettigheder. Inden for liberalisme er der uenighed om hvad disse rettigheder består i, og om hvad der udgør begrundelsen for dem (jf. Kymlicka, 2002). De fleste liberale nationalister, særligt Miller, er dog mere eller mindre socialliberale, hvorfor liberalisme her forstås som et forholdsvist egalitaristisk synspunkt i stil med det der findes hos den tidlige Rawls, dvs. at de individuelle rettigheder ud over borgerlige frihedsrettigheder omfatter relativt generøse sociale rettigheder der begrunder statslig sikring af lige muligheder og omfordeling af goder. ${ }^{3}$

Ud over at være liberal i denne forstand, hævder liberal nationalisme yderligere norrnative påstande der gør synspunktet til en form for nationalisme. Synspunkter 
kan generelt betegnes som nationalistiske når de hævder at stat og nation så vidt muligt bør være sammenfaldende (Lægaard, 2002). Dette kan blandt andet forstås sådan at borgere i staten bør være medlemmer af den samme nation $\mathrm{i}$ den forstand at de bør have en fælles national identitet. Det er denne normative påstand der her tages som definerende for nationalisme. Spørgsmålet er hvad begrundelsen for påstanden er, og hvilke implikationer den har, dvs. hvilke politiske tiltag der kan forsvares ud fra den.

Som begrundelse hævdes at en fælles national identitet er en forudsætning for social solidaritet og dermed for at et liberalt samfund kan være stabilt i praksis. Kald denne faktuelle påstand "forudsætningstesen". Miller opererer med to varianter heraf som behandles i to afsnit nedenfor. Bemærk at der er to led i den påståede forudsætningssammenhæng: For det første hævdes en fælles national identitet at være en forudsætning for solidaritet, og for det andet hævdes solidaritet at være en forudsætning for opretholdelse af en liberal samfundsorden. En fælles national identitet ses som svaret på problemet om social enhed, og det er som sådan synspunktet inkorporerer kommunitaristiske ideer (jf. Kymlicka, 2002: 252-261). Liberal nationalisme er således en form for instrumentelt og indirekte begrundet nationalisme, idet en fælles national identitet ikke i sig selv hævdes at begrunde nationalisme: En fælles national identitet er udelukkende ønskværdig fordi den hævdes at medføre solidaritet. ${ }^{4}$ Begrundelsen for nationalisme er endvidere empirisk informeret, idet forudsætningstesen er en faktuel påstand hvis rimelighed er et empirisk spørgsmål.

Hvad angår synspunktets politiske implikationer, er staten kun begrundet $\mathrm{i}$ at fostre og opretholde en fælles national identitet for så vidt dette er foreneligt med liberalisme. Eftersom solidaritet ifølge liberal nationalisme ikke er et mål i sig selv, men kun et middel til opretholdelse af en liberal samfundsorden, medfører synspunktet kun at solidaritet bør sikres inden for rammerne af liberalisme. Denne restriktion, som altså følger af at en liberal samfundsorden er det egentlige mål, kan kaldes "forenelighedskravet" og gælder i to henseender: Dels må de midler, staten anvender for at skabe og opretholde en fælles national identitet blandt borgerne, ikke krænke disses rettigheder, og dels skal indholdet af den fælles nationale identitet i sig selv være liberalt acceptabelt. Kravet til indholdet skyldes at folk ifølge liberalisme har forskellige "opfattelser af det gode", for eksempel forskellige religiøse eller ideologiske overbevisninger, og at personer skal have frihed til at tage disse opfattelser op til kritisk eftersyn og på baggrund heraf kunne revidere eller forkaste dem (jf. Kymlicka, 1995: 80ff.). Der er forskellige begrundelser herfor, men lige gyldigt hvad begrundelsen er, vil det ikke give mening at kalde et synspunkt liberalt hvis det kræver at folk indordner sig under en national identitet der omfatter en bestemt opfattelse af det gode. En national identitet er kun liberalt acceptabel hvis det at have denne identitet er foreneligt med revision eller forkastelse af opfattelser af det gode. Liberal nationalisme benægter et bestemt liberalt ideal om statslig neutralitet idet staten aktivt skal anerkende, understøtte og fostre en officiel, fælles national identitet (Miller, 1995: 137, 195; jf. Kymlicka, 1995), men hvis synspunktet skal kunne kaldes liberalt, må det udelukke statslig brug af tvang eller tilsidesættelse af borgernes rettigheder. 
Som karakteriseret her, er liberal nationalisme defineret af forudsætningstesen og det heraf følgende forenelighedskrav. Bemærk at dette indikerer et muligt problem for liberalisme i almindelighed: Hvis en fælles national identitet er en nødvendig forudsætning for et liberalt samfund, men forudsætningen ikke kan indfris uden at krænke liberalisme, så er der tale om et reductio argument imod liberalisme. I så fald er liberalisme selvgendrivende; en liberal samfundsorden vil aldrig være stabil uden brug af midler der undergraver den selv samme orden. Liberal nationalisme er defineret ved påstanden om at det er muligt at forene politiske tiltag med henblik på sikring af en fælles national identitet med liberalisme, samt af en bestemt opfattelse af nationsbegrebet. I det følgende redegøres for nationsbegrebet som det optræder i forudsætningstesen, og derefter for de to argumenter for forudsætningstesen. Derpå følger en mere kritisk diskussion af Millers opfattelse af nationen, og det beskrives hvorledes begrebet herom i liberal nationalisme ikke udtømmes af den rolle det spiller i forudsætningstesen.

\section{Begrebet om nationen}

Karakteristikken af nationalisme kræver en præcision af hvad der forstås ved "nation" og "national identitet". Ved at putte forskellige nationsbegreber ind i definitionen vil man få forskellige synspunkter med forskellige implikationer. Derfor er bestemmelse af hvad der forstås ved "national identitet" afgørende for vurderingen af synspunktets plausibilitet, idet begrundelsen afhænger af om en fælles national identitet $\mathrm{i}$ den relevante forstand faktisk kan generere solidaritet. Bestemmelsen kan dog ikke blot bestå i import af et fastlagt nationsbegreb fra den empiriske forskning i nationer. Dette skyldes for det første at der inden for forskningen er flere forskellige og konkurrerende teorier om hvad en nation er, og om nationers sociale funktion og historiske oprindelse. For det andet skyldes det at nationer ikke er naturlige, uforanderlige eller præpolitiske fænomener. Nationer er tvært imod produkter af historiske, politiske og sociale omstændigheder, intenderet "nation-building", og er ofte opstået på baggrund af bestemte politiske grænsedragninger frem for omvendt. Ud over at undergrave ideen om nationer som "oprindelige", betyder dette at "nation" ikke er en uproblematisk deskriptiv term, men et i sig selv politisk ladet begreb, både med hensyn til indhold, og hvad angår anvendelsen af det om bestemte grupper. Anvendelsen af begrebet markerer en politisk diskurs eller retorik der tilføjer en normativ dimension til forståelsen af sociale grupper, hvorfor betegnelsen af en bestemt gruppe som en nation i sig selv kan være udtryk for nationalisme (Calhoun, 1995: kap. 8; Özkirimli, 2000: 220f., 229f.). Nationer kan altså ikke betragtes som sociale størrelser uafhængigt af den politiske sammenhæng de bruges $i$, dvs. uafhængigt af nationalisme. I diskussionen af liberal nationalisme er nationsbegrebet derfor ikke et neutralt, deskriptivt element.

Miller karakteriserer nationer - til forskel fra både stater og etniske grupper (Miller, 1995: 18-21) - som grupper med følgende kendetegn:

1. Nationalitet konstitueres af at personer dels subjektivt opfatter sig som værende medlemmer af en nation og dels gensidigt anerkender hinanden som værende medlemmer (Miller, 1995: 17f., 22f., 32, 2000: 28). 
2. National identitet er identifikation med et historisk fællesskab: Folk føler sig forpligtigede af tidligere generationers handlinger og over for fremtidige generationer (Miller, 1995: 23f., 2000: 28f.).

3. National identitet er en "aktiv" identitet, dvs. at nationens medlemmer identificerer sig med hinandens sejre og nederlag, og føler at de kan handle som en gruppe (Miller, 1995: 24, 2000: 29).

4. National identitet omfatter identifikation med et bestemt geografisk territorium, dvs. at nationer har "hjemlande" og normalt efterstræber suverænitet herover i form af en nationalstat på dette territorium (Miller, 1995: 24f., 2000: 29f.).

Individers identifikation eller følelse af forpligtigelse er altså ifølge Miller afgørende for om en gruppe udgør en nation. Nationalitet konstitueres af subjektive opfattelser og det er værd at understrege at det ikke er afgørende om disse opfattelser er korrekte eller ej, for eksempel er det underordnet om opfattelsen af nationens historie i en gruppes selvopfattelse er sandfærdig (Miller, 1995: 34-41, 2000: 31; Özkirimli, 2000: 222). På disse punkter er Millers begreb i overensstemmelse med Benedict Andersons karakteristik af nationer som "imagined communities" (Anderson, 1991), lige som det politiske element i punkt 4 stemmer med den "modernistiske" opfattelse af nationen som en moderne form for politisk mobilisering der først for alvor dukker op i det attende århundrede på baggrund af demokratiske ideer om folket som kilde til suverænitet og legitimitet (Miller, 1995: 29f.; Özkirimli, 2000: kap. 4). At nationer er subjektive, moderne og konstruerede, er foreneligt med at konstruktionen i mange tilfælde har taget udgangspunkt i allerede eksisterende etniske kategorier, som såkaldte "etno-symbolister" hævder (Özkirimli, 2000: kap. 5), men åbner samtidig mulighed for udbredelse af nationen ud over de oprindelige etniske opdelinger til i princippet at omfatte alle borgere inden for en given stat.

Miller tilføjer dog et yderligere, objektivt element til definitionen:

5. National identitet kræver en "fælles offentlig kultur", dvs. at medlemmerne af en nation har bestemte kulturelle karakteristika til fælles:

"... a national identity requires that the people who share it should have something in common, a set of characteristics that in the past was often referred to as a 'national character', but which I prefer to describe as a common public culture ... There must be a sense that the people belong together by virtue of the characteristics they share" (Miller, 1995: 25).

Den fælles offentlige kulturs indhold er selvsagt forskelligt fra nation til nation, men Miller giver nogle få eksempler på, hvad han mener en sådan kan indeholde, for eksempel:

"A public culture may be seen as a set of understandings about how a group of people is to conduct its life together. This will include political principles such as a belief in democracy or the rule of law ... social norms, such as filling in your tax return or queuing as a way of deciding who gets on the bus first. It may also embrace certain cultural ideals, for instance religious beliefs or a commitment to preserve the purity of the national language" (Miller, 1995: 26). 
Ud over sådanne eksempler er det uklart hvad Miller mere generelt mener med "fælles offentlig kultur", og dermed ved national identitet. Det afgørende er at fælles offentlige kulturer giver konkrete nationale identiteter et specifikt indhold, som sådan sikrer solidaritet, og dermed underbygger forudsætningstesen. Efter redegørelsen for Millers argumenter for liberal nationalisme i de to følgende afsnit, tages Millers nationsbegreb og de politiserede aspekter ved det op til nærmere diskussion.

\section{Instrumentelle argumenter I: social retfærdighed}

I dette afsnit fokuseres på de af Millers argumenter der hævder at en fælles national identitet er et middel til at tilvejebringe betingelserne for realiseringen af liberale værdier. Miller har to varianter af denne slags argumenter, der henholdsvis omhandler betingelserne for social retfærdighed i form af omfordeling af goder og betingelserne for realisering af et bestemt demokratiideal. ${ }^{5}$

Millers første argument tager udgangspunkt i at en velfærdsstat af socialdemokratisk eller socialliberalt tilsnit er ønskværdig. Det er sådanne staters opgave at sikre social retfærdighed hvilket normalt indebærer omfordeling blandt borgerne. Spørgsmålet er hvad der kan få borgeme til at støtte omfordelingen. Miller tager for givet at opretholdelse af social retfærdighed ikke bør finde sted alene ved statslig tvang, men bør opfattes som demokratisk legitim af flertallet af borgere (Miller, 1988-89: 57; jf. Canovan, 1996: kap. 4). Hvad kan sikre dette?

"... nationality answers one of the most pressing needs of the moderm world, namely how to maintain solidarity among the populations of states that are large and anonymous ... it is potentially difficult to mobilize people to provide collective goods, it is difficult to get them to agree to practices of redistribution from which they are not likely personally to benefit, and so forth ... Nationality is de facto the main source of such solidarity" (Miller 2000: 31f.; se tilsvarende Miller, 1995: 83ff., 93).

Miller kommer altså med to påstande:

1. Den omfordeling der kræves af idealet om social retfærdighed, har som nødvendig forudsætning at de borgere imellem hvilke omfordelingen skal finde sted, er solidarisk indstillede over for hinanden.

2. En fælles national identitet er et effektivt middel til at sikre solidaritet.

Dette rejser en række spørgsmål:

1. Kan omfordeling sikres på andre måder end via solidaritet?

2. Kan solidaritet sikres på andre måder end via en fælles national identitet?

3. Er en fælles national identitet en tilstrækkelig betingelse for solidaritet?

Der findes $\emptyset$ jensynlig fremtrædende fortalere for synspunktet at solidaritet ikke er nødvendig for at sikre omfordeling. For eksempel er det ifølge Rawls en tilstrækkelig betingelse for opbakning til institutioner der varetager omfordeling, at borgeme der er underlagt institutionerne har "a normally effective sense of justice" 
hvilket er et af elementerne i et "velordnet" og dermed stabilt samfund (Rawls, 1993: 35). ${ }^{6}$ At have en fornemmelse for retfærdighed er ikke det samme som at være solidarisk med andre borgere. En effektiv fornemmelse for retfærdighed består $\mathrm{i}$ at anerkende retfærdighedsprincipperne som velbegrundede og acceptere institutioner som retfærdige for så vidt de lever op til disse principper, samt generelt at handle i overensstemmelse med disse institutioner. Det er derfor principielt muligt at have en formemmelse for retfærdighed uden at føle solidaritet med de andre borgere.

Rawls' ideer om borgere som havende en effektiv fomemmelse for retfærdighed og om samfundet som velordnet er dog særdeles ideale forestillinger. Det er klart at omfordeling ville være sikret $i$ et velordnet samfund hvor borgerne havde en effektiv fornemmelse for retfærdighed, for dette betyder per definition at de ville handle i overensstemmelse med retfærdighedsprincipperne, dvs. bidrage til omfordeling. Men ét er at definere hvad det vil sige at have en effektiv fornemmelse for retfærdighed, noget andet er at sikre at borgerne i samfundet faktisk har dette, hvilket blandt andet kommunitarister påpeger. Miller kan svare at det der kan sikre at borgeme har en fornemmelse for retfærdighed, er at de har en fælles national identitet og dermed er solidariske over for hinanden.

Det næste spørgsmål er om en fælles national identitet er en nødvendig betingelse for solidaritet. Hvis dette ikke er tilfældet, vil det svække argumentet for nationalisme markant da der jo i så fald vil være andre måder at opnå målet, social retfærdighed, på. For at svare på dette spørgsmål må man se sig omkring efter faktiske eller tænkelige modeksempler. Dette indebærer en præcision af begrebet om en fælles national identitet, da bestemmelsen heraf afgør om et tilfælde udgør et modeksempel. Således kunne man pege på lande som Canada, Belgien og Svejts som eksempler på velfærdsstater der ikke desto mindre er multi-nationale. Disse eksempler kunne altså tyde på at en fælles national identitet ikke er nødvendig for at sikre omfordeling. Miller erkender denne mulige indvending, men svarer ved at benægte at der er tale om modeksempler da de nævnte lande godt nok er multinationale, men samtidig har en fælles national identitet $i$ den forstand han er interesseret i (Miller, 1995: 94ff.). Forudsætningstesen forsvares altså imod modeksemplerne ved at begrebet om hvad det vil sige at borgere har en fælles national identitet, gøres foreneligt med at borgerne er medlemmer af forskellige nationer.

Dette svar kunne lyde ad hoc og endda selvmodsigende, men kan opretholdes hvis der kan være tale om grader af national identitet, eller nationale identiteter på forskellige niveauer. Millers påstand er åbenbart at omfordeling forudsætter en fælles national identitet (medieret af solidaritet), men at denne fælles identitet kan være på et så overordnet niveau at den tillader substantielle forskelle med hensyn til sprog (engelsk/fransk, fransk/flamsk, fransk/tysk/italiensk), religion (protestantisk/katolsk) og kultur. Herved undgår Miller modeksemplerne, men kun ved at gøre begrebet om en fælles national identitet så bredt at spørgsmålet bliver hvad det er i den fælles nationale identitet der genererer solidaritet. Dette spørgsmål diskuteres nærmere nedenfor.

Først skal det bemærkes at der er yderligere potentielle modeksempler end de nævnte. For eksempel er der tale om en omfattende omfordeling fra Storbritannien 
til Nordirland, på trods af at et stort flertal i den britiske befolkning ikke betragter de nordirske unionister - og heller ikke de nordirske republikanere, for den sags skyld - som medlemmer af den britiske nation. Dette kan dog forklares med at der på det tidspunkt hvor omfordelingen blev etableret, faktisk var en national fællesskabsfølelse mellem briter og nordirere, som dog siden hen er forsvundet på grund af urolighederne i Ulster (Moore, 2001: 82f.).

Endnu et eksempel kunne være forholdet mellem Danmark og de nordatlantiske selvstyreområder. Umiddelbart har danskere, færinger og grønlændere ikke en fælles national identitet - de taler forskellige sprog, har forskellige "hjemlande" og forskellige kulturer - og alligevel finder der store overførsler af midler sted fra Danmark til selvstyret og landsstyret. Stillet over for dette eksempel vil Miller igen kunne hævde at der faktisk er en fælles national identitet $\mathrm{i}$ den overordnede forstand han har i tankerne, måske i kraft af fælles kongehus, historie og institutioner, men herved ville han igen trække nationsbegrebet i retning af et "tyndt" fællesskab hvor det er mindre klart hvad der genererer solidaritet.

Hvad angår spørgsmålet om en fælles national identitet er tilstrækkelig for at sikre solidaritet, er der også grunde til at betvivle sammenhængen. Der forekommer nemlig at være klare eksempler på stater hvor der er en relativt stærk fælles national identitet, men hvor der ikke er den store solidaritet. Det oplagte eksempel herpå er USA hvor der findes en meget stærk national bevidsthed og patriotisme, men som man næppe kan betegne som en solidarisk velfærdsstat (Moore, 2001: 8 lf.). Miller imødegår denne indvending ved at hævde at

"... it is not only the strength of national identity ... but also the character of national identity that matters ... national identities embod[y] a shared public culture. The quality of that culture -in particular, the extent to which the nation conceives itself along solidaristic or individualistic lines - is clearly going to be of vital importance" (Miller, 1995: 94).

Miller indrømmer altså at en fælles national identitet ikke er tilstrækkelig for at sikre solidaritet; der er derudover behov for at nationens fælles offentlige kultur er solidarisk. Dette betyder at forudsætningstesen ikke kan opretholdes i en stærk version der hævder at en fælles national identitet er en nødvendig og tilstrækkelig betingelse for solidaritet. Hvis tesen stadig skal kunne begrunde nationalisme, må den omformuleres til en svagere version der hævder at en fælles national identitet kun er en nødvendig betingelse, men at den sammen med en solidarisk offentlig kultur er tilstrækkelig for solidaritet. Dette betyder at Millers argument kun støtter nationalisme i de tilfælde hvor den fælles nationale offentlige kultur faktisk er solidarisk, hvilket blandt andet udelukker et argument af denne slags for amerikansk nationalisme.

Millers forsvarsmanøvrer mod de potentielle modeksempler til forudsætningstesen er dog problematiske, idet tesen reduceres til en nærmest tautologisk påstand: Hvis folk er solidariske (i kraft af en solidarisk offentlig kultur), så er de solidariske. Spørgsmålet er hvilken af de to tilsammen tilstrækkelige betingelser der er den vigtigste kilde til solidaritet i et samfund, en fælles national identitet eller en solidarisk offentlig kultur, og om en sådan kultur kan tænkes uafhængigt 
af en fælles national identitet? Hvis dette er tilfældet, er den fælles nationale identitet forsvundet som forklarende faktor. Millers svar på de første modeksempler kan tolkes derhen at en fælles solidarisk offentlig kultur faktisk er mulig på tværs af forskellige nationer. At han insisterer på fortsat at tale om en fælles national identitet $\mathrm{i}$ disse tilfælde, kunne blot være en forveksling af genus med species: Nationer er eksempler på grupper med fælles offentlige kulturer og kan som sådan være solidariske, men ikke alle fælles offentlige kulturer er nationale. Hvis dette er tilfældet, svækkes argumentet for nationalisme markant da en fælles national identitet så ikke engang vil være nødvendig for solidaritet. Miller har altså ikke påvist en klar forbindelse mellem national identitet og solidaritet, og i stedet for at give et mere præcist indhold til begrebet om nationen har hans undvigemanøvrer gjort det mere uklart hvad der tæller som en national identitet.

\section{Instrumentelle argumenter II: demokrati}

Millers andet instrumentelle argument tager udgangspunkt i et ideal om demokrati, lige som det første argument tog udgangspunkt i et ideal om social retfærdighed. Demokrati er ikke en entydigt defineret størrelse, tvært imod er der en lang række forskellige opfattelser af hvad der er definerende for demokrati, og af hvad der i givet fald gør demokrati til en attraktiv styreform. I denne debat erklærer Miller sig som tilhænger af såkaldt deliberativt demokrati (Miller, 1995: 96; 2000: 9ff., 142). Da emnet for denne artikel ikke er teorier om demokrati, men liberal nationalisme, skitseres det kun meget nødtørftigt hvad der forstås ved deliberativt demokrati, lige som det foregående afsnit ikke gik ind i debatten mellem forskellige syn på social retfærdighed. Dette skyldes dels at det relevante i denne forbindelse udelukkende er hvordan idealet om deliberativt demokrati kan fungere som del af et instrumentelt argument for liberal nationalisme, og dels at der selv blandt tilhængere af deliberativt demokrati er store forskelle med hensyn til karakteristikken af dette bestemte demokratiideal (se Andersen og Hansen, 2002: 80ff.).

Som navnet siger er det centrale i demokrati ifølge tilhængere af deliberativt demokrati "deliberation", dvs. en særlig form for demokratisk samtale, hvori synspunkter fremsættes, begrundes og diskuteres. Herved adskiller deliberativt demokrati sig fra opfattelser der for eksempel ser afstemning som det definerende træk ved demokrati. Ifølge deliberativt demokrati bør man kun skride til afstemning på baggrund af deliberation, og idealet er at afstemning slet ikke er nødvendig fordi deltagerne i den demokratiske diskussion kan ændre deres synspunkter under indtryk af argumenter, information og andre perspektiver på sagen der kommer for dagen i løbet af processen. Dette vil sige at der kan skelnes mellem deliberation og "studehandel", idet deliberation handler om at give gode grunde og ideelt set at nå til enighed frem for at sikre sig det mest fordelagtige kompromis. Da præferencerne hos deltageme i den demokratiske debat ifølge tilhængere af deliberativt demokrati kan ændre sig undervejs, kan man skelne mellem deliberativt demokrati og den opfattelse Miller kalder "liberalt demokrati", ifølge hvilken præferencer er fastlagte forud for den demokratiske proces (Miller, 2000: 9).

Hvad angår spørgsmålet om, hvorfor demokrati er en værdifuld styreform, handler "liberalt demokrati" om at aggregere borgernes forudgivne præferencer inden 
for grænser sat af konstitutionelt sikrede individuelle rettigheder. I modsætning hertil fokuserer mange deliberative demokrater på legitimitet (se Cohen, 1997; Freeman, 2000). Tanken er groft sagt at borgere lettere vil kunne acceptere at blive nedstemt hvis de er blevet hørt, har fået lejlighed til at fremsætte og argumentere for deres opfattelser, og ved inddragelsen i beslutningsprocessen er blevet anerkendt som rimelige borgere med legitime interesser. Derudover undgår deliberativt demokrati en række problemer med "liberalt demokrati" der skyldes at ingen afstemningsregler kan sikre at den trufne beslutning svarer til borgernes præferencer (Miller, 2000: kap. 1).

Det i denne artikels sammenhæng relevante er at deliberativt demokrati, lige gyldigt hvilken variant eller begrundelse herfor der er tale om, er et meget krævende ideal. For at talen om saglig diskussion og argumentation ikke blot skal være retorik der dækker over interessegruppers strategiske fors $\emptyset \mathrm{g}$ på at pleje egne interesser, er det ikke nok at den demokratiske proces omfatter debat og høring af berørte parter. Det kræves derudover at borgere faktisk er villige til at deltage, høre de fremsatte argumenter og lade sig flytte af disse, for så vidt de er gode. Alle skal have et motiverende ønske om at få etableret konsensus eller $i$ hvert fald at kunne begrunde den resulterende beslutning over for alle der påvirkes af den, med grunde som kan accepteres som gode af alle rimelige personer. Borgerne skal altså sætte målet om at nå til enighed og kunne begrunde beslutninger over for berørte parter højere end målet om at opfylde egne interesser.

Hvordan kan man sikre dette i praksis? Millers svar er at der er brug for den samme solidaritetsfølelse som var en betingelse for opbakning til omfordeling: "Among large aggregates of people, only a common nationality can provide the sense of solidarity that makes this possible" (Miller, 1995: 98). ${ }^{7}$ Millers argument er altså at demokrati primært er en attråværdig styreform for så vidt det er deliberativt, og at en fælles national identitet er en nødvendig betingelse for den motivation dette kræver af borgerne.

Til dette argument for ønskværdigheden af at borgerne i staten har en fælles national identitet, kan man stille de samme spørgsmăl som til det første instrumentelle argument, nemlig (1) om det er korrekt at et velfungerende demokrati kræver denne form for solidaritetsfølelse, (2) om det er rigtigt at en fælles national identitet er en nødvendig betingelse for solidaritet, og (3) om den evt. også er en tilstrækkelig betingelse herfor. Spørgsmål (1) vil ikke blive diskuteret nærmere idet dette kun lader sig gøre i forhold til en specificeret variant af idealet om deliberativt demokrati. Ligeledes vil der heller ikke være nogen diskussion af Millers svar på spørgsmål (2) og (3), da en sådan ville have samme struktur som diskussionen af det første argument. I stedet gælder det nu diskussionen af hvordan Miller undervejs præciserer og kvalificerer sit begreb om en fælles national identitet.

\section{Et politiseret begreb om nationen}

Allerede kvalifikationerne af begrebet om en fælles national identitet og offentlig kultur i forbindelse med det første argument indikerer at nationale identiteter ifølge liberal nationalisme i sig selv er genstande for politiske vurderinger og krav. Kravet om en solidarisk offentlig kultur peger i retning af pointen i dette afsnit, nem- 
lig at forudsætningstesen i liberal nationalisme ikke bør forstås som en uproblematisk kausal påstand om et forhold mellem en liberal samfundsorden og bestemte herfra uafhængige betingelser for tilstedeværelsen af en fælles national identitet. Den liberale nationalismes instrumentelle holdning til nationale identiteter $\mathrm{g} \emptyset \mathrm{r}$ sig ikke kun gældende med hensyn til spørgsmålet om staten skal fremme en fælles national identitet, men i lige så høj grad med hensyn til hvilken identitet der i givet fald bør fremmes. Indholdet i en fælles national identitet er altså i sig selv til politisk diskussion.

Dette element $\mathrm{i}$ liberal nationalisme kan ses som en mere omfattende variant af det jeg tidligere kaldte forenelighedskravet. Det var en betingelse der skulle forhindre at midlet (statslig fremme af en fælles national identitet) undergraver målet (en liberal samfundsorden). Men Miller stiller yderligere betingelser til fælles offentlige kulturer:

For det første bemærker Miller at omfanget af den offentlige kultur "will vary from case to case, but it will leave room for different private cultures within the nation" (Miller, 1995: 26). Miller understreger gentagne gange hvor rummelige og forenelige med individuelle forskelle, nationale identiteter i hans forstand er, og at nationale kulturer ikke er altomfattende, men tvært imod levner rum for forskelle med hensyn til politiske synspunkter, religiøse overbevisninger, livsstile, og meget andet (Miller, 1995: 25ff., 85f., 98, 121, 2000: 30), for eksempel: "Sharing a national identity does not, of course, mean holding similar political views; but it does mean being committed to finding terms under which fellow-nationals can agree to live together" (Miller, 1995: 98). Det er afgørende at den fælles nationale kultur er offentlig; den omfatter politiske principper for indretningen af samfundet og normer for social omgang, men ikke privatlivet - eller den behøver i hvert fald ikke at gøre det hvis der i samfundet er forskellige opfattelser af det gode. For det andet er nationale identiteter ikke fastlagt én gang for alle, men er historisk foranderlige, og deres indhold skal som sådan være genstand for løbende demokratisk diskussion og kritik (Miller, 1995: 127).

Det første punkt kan forstås som et forsøg på at sikre at det resulterende synspunkt vil være foreneligt med liberalisme. Det er dog bemærkelsesværdigt at Miller ikke blot stiller krav om at de politiske tiltag der skal sikre en fælles national identitet, skal respektere individers rettigheder. Han går, som det fremgår af citaterne, videre og karakteriserer det at have en fælles national identitet $\mathrm{i}$ den relevante forstand på en måde der er et direkte og utilsløret udtryk for liberalisme. Det grundlæggende liberale projekt er netop at formulere retfærdige betingelser som personer med forskellige opfattelser af det gode kan leve sammen under. Miller hævder altså ikke blot at en fælles nationalitet kan sikres på en måde der er forenelig med dette projekt, men at en fælles national identitet i hans forstand ligefrem er udtryk for det.

Miller underordner således den fælles nationale kultur under en klassisk liberal figur, nemlig skellet mellem det offentlige og det private. Skellet havde oprindeligt til funktion at gøre forskelle med hensyn til religiøs overbevisning forenelige med fælles politisk tilhørsforhold, og dannede som sådan grundlag for den traditionelle liberale tolerancemodel: Religiøse overbevisninger "privatiseres" og 
forskellene i privatsfæren beskyttes af individuelle frihedsrettigheder (Barry, 2001: kap. 2). Når Miller understreger at den fælles kultur ikke angår det private, er dette en måde at sige på at den skal underordnes det liberale krav om neutralitet i den forstand at alle borgere kan acceptere og deltage i den. Selv om liberal nationalisme som nævnt forkaster idealet om en neutral stat, dukker neutralitetsidealet altså op igen som del af Millers begreb om nationen. Der er tale om neutralitet relativt til de forskelle der er inden for staten, men om markering af forskel til andre nationer på en måde som skal sikre solidaritet (jf. Poulsen, 1998: 140f.).

Det andet punkt der underordner den nationale identitets indhold under demokratiidealet, kommer særligt til udtryk i Millers diskussion af hvilke krav det er legitimt at stille til immigranter, og af hvad der kan forstås ved en fælles national identitet i multikulturelle samfund: Den nationale identitet skal være modtagelig over for immigranter, forudsat de er tilpasningsvillige, dvs. at integration bør være en gensidig tilpasning mellem den nationale identitet og immigranters identiteter. Det eneste krav Miller stiller til immigranter er at de accepterer eksisterende liberale institutioner og engagerer sig i debatten om hvori en national identitet der kan være fælles for både indfødte og nytilkomne, kan bestå (Miller, 1995: $128 \mathrm{ff}$.). Hvis der for eksempel er religiøse forskelle, bør den nationale identitet således "renses" for religiøse elementer (Miller, 1995: 137). Den nationale identitet skal løbende tilpasses multikulturelle forhold ved at elementer der forhindrer at immigranter og minoriteter kan tage del i den, "privatiseres" (Miller, 1995: 142). Dette skal endelig ske i en åben demokratisk diskussion hvor alle, både indfødte og nytilkomne, tager del: "... the public culture is not set in aspic, but changes over time under the impact of ethnic and other group cultures. As concrete issues are decided, people's sense of what it means to belong to this political community gradually shifts" (Miller, 1995: 150).

På baggrund af disse to kvalifikationer fremgår det at en fælles national identitet ifølge liberal nationalisme skal være udtryk for helt bestemte liberale og demokratiske værdier. En national identitet er altså ikke blot en ydre betingelse for realisering af en liberal samfundsorden, som forudsætningstesen hævder, men i sig selv en politisk arena. At nationsbegrebet defineres på denne måde, er ensbetydende med at liberal nationalisme stiller indholdsmæssige krav til konkrete nationale identiteter: De skal ikke alene være forenelige med, men ligefrem være udtryk for liberalisme. En mulig måde at forstå dette på er at en national identitet udelukkende består i en identifikation med et politisk fællesskab, dvs. med den demokratiske proces hvor spørgsmål om fælles anliggender debatteres, og at den nationale kultur er de normer for opførsel og de politiske principper der ligger til grund for denne debat $\mathrm{i}$ den offentlige sfære. ${ }^{8}$

Det interessante er dog at Miller i andre sammenhænge understreger at en national identitet er andet og mere end identifikation med politiske institutioner eller med de politiske principper der ligger til grund herfor, som det for eksempel er tilfældet i Habermas' "konstitutionelle patriotisme" (Habermas, 1996; Markell, 2000). Identifikation med grundlovssikrede principper er, ifølge Miller, ikke tilstrækkelig for en fælles national identitet, idet de er for abstrakte til at sikre solidaritet. Liberale forfatninger er nogenlunde ens hvad angår de universelle politi- 
ske værdier de knæsætter, og ud fra liberale principper alene er det ikke muligt at bestemme hvor grænser for stater eller for borgerskab skal drages. Hvis forskellige staters grundlove er udtryk for de samme politiske principper, kan de derfor ikke sikre solidaritet med en bestemt afgrænset gruppe hvilket, ifølge Miller, netop er det en national identitet skal gøre.

Man kunne hævde at dette ikke er en legitim indvending mod forfatningspatriotisme da landegrænser i praksis normalt ligger fast, hvorfor de kan tages for givne med henblik på afgrænsning af patriotiske fællesskaber. Forfatningens principper kan godt være fokus for en fælles identitet blandt borgerne inden for givne institutionelle grænser. Men Miller accepterer ikke dette forsvar: "to say this is to beg the question, for what settles boundaries is precisely a shared sense of nationality" (Miller, 1995: 163). Her blander Miller dog sit eget normative princip for hvori landegrænsers legitimitet består sammen med hvordan disse faktisk er kommet i stand. Det er jo ganske enkelt forkert at politiske grænser generelt er draget efter grænserne for nationale grupper. Politiske grænser er tvært imod historiske produkter af politiske forhandlinger, krige og dynastiske forhold fra før nationer og nationalstater overhovedet eksisterede i moderne forstand. Det forholder sig oftest stik modsat af hvad Miller hævder: Følelser af fælles nationalitet er produkter af politiske grænsedragninger (og efterfølgende "nation-building"), frem for omvendt. Det interessante er at Miller i andre sammenhænge som sagt dels anerkender nationers konstruerede karakter og dels stiller indholdsmæssige krav til nationale identiteter om at de bør være liberale og (om)formes i en demokratisk proces. Men når han skal distancere sig fra Habermas' konstitutionelle patriotisme, appellerer han pludselig til et begreb om nationen som eksisterende forud for og uafhængigt af den politiske proces. Det kan derfor være svært at tage hans kritik af forfatningspatriotisme alvorligt. Mere interessant er det at Miller øjensynligt opererer med forskellige begreber om nationalitet $i$ forskellige sammenhænge.

\section{National identitet: modsatrettede krav}

Millers glidning mellem forskellige nationsbegreber i forskellige sammenhænge er forståelig hvis man erindrer hvad projektet i liberal nationalisme er. Idealet er som sagt at en fælles national identitet dels sikrer solidaritet og dels er udtryk for liberale og demokratiske værdier. Problemet er at disse to mål kan vise sig at trække nationale identiteter i hver sin retning, og at de måske i det hele taget er uforenelige.

Det er i det foregående blevet vist at Miller på den ene side fremstiller nationale identiteter som ikke alene forenelige med, men som udtryk for liberalisme. På den anden side er den fælles offentlige kultur det der skal sikre at folk med en fælles national identitet vil have tilstrækkeligt meget til fælles, til at de faktisk vil udvise den solidaritet der skal til for at den fælles nationale identitet kan udfylde sin funktion i de instrumentelle argumenter. Men så snart Miller skal præcisere i hvilken forstand en national identitet går ud over det rent politiske, kommer han til at karakterisere nationalitet på måder der risikerer at være uforenelige med pluralisme og demokratisk debat og kritik. Her spøger en opfattelse af nationalitet som 
præpolitisk, hævet over kritik, og som en medfødt og traditionelt given del af personers identitet der ikke er genstand for valg (Miller, 1995: 41-45, 194). ${ }^{9}$

Denne måde at skildre nationalitet på svarer ganske godt til en udbredt, i sidste ende romantisk, ide om nationen som et "oprindeligt" etnisk-kulturelt fællesskab som man fødes ind i; en forestilling der stadig lader til at indgå i mange danskeres selvopfattelse. Et sådant begreb om nationen er dog problematisk i forhold til liberal nationalisme. En måde at formulere problemet på er at Miller forsøger at forene to forskellige typer solidaritet: På den ene side er han tilhænger af en fælles national identitet forstået som et givent, afgrænset fællesskab man fødes ind i, fordi denne slags fællesskab historisk set har sikret en form for mekanisk solidaritet. På den anden side er han liberal hvilket vil sige at grundlaget for solidaritet bør være genstand for forhandling og i princippet skal kunne udvides til alle personer der går ind på de gensidigt acceptable præmisser for fællesskabet. Dette er en voluntaristisk og kontraktteoretisk opfattelse af solidaritet der grundlæggende strider mod eller i hvert fald står i et anspændt forhold til synet på solidaritet som noget præpolitisk, givent og mekanisk. Stillet over for de to definerende krav i liberal nationalisme har Miller derfor en tendens til at glide fra en tilstræbt deskriptiv redegørelse for hvori nationalfølelse faktisk består, når han skal redegøre for nationalitet som kilde til solidaritet, til et mere idealiseret billede af hvorledes kollektive identiteter burde være rummelige og genstand for demokratisk debat, når han skal fremstille nationalitet som forenelig med og udtryk for liberalisme.

Nationsbegrebet er altså genstand for modsatrettede krav. Miller søger som beskrevet at forene ambitionerne ved at omdefinere hvad han forstår ved en fælles national identitet. Dels gøres denne uafhængig af private forskelle for at være forenelig med det traditionelle liberale skel mellem offentligt og privat, dels gøres dens indhold til genstand for demokratisk forhandling. Spørgsmålet er blot om denne modifikation ikke sker på bekostning af nationale identiteters evne til at sikre den krævede form for solidaritet. I så fald er strategien i realiteten udtryk for at liberalisme vægtes på bekostning af solidariteten, til trods for at Miller bibeholder den nationale terminologi. Derudover er der et andet problem med Millers strategi: Den nationale identitet er nødvendig for at gøre idealet om deliberativt demokrati plausibelt, idet de krav der stilles til borgeres motivation kan forekomme naive og urealistiske uden en forudgående gensidig solidaritet. Men i så fald er det et problem at Miller samtidig putter det idealiserede element, som er det der overhovedet gør demokratiidealet problematisk - måske utopisk - ind i nationsbegrebet.

Miller kan altså anklages for at blande et begreb om hvad der historisk set har genereret solidaritet, og et ideal om hvorledes solidaritet bør genereres, sammen. En fælles national identitet har muligvis spillet den solidaritetssikrende rolle, ${ }^{10}$ men det er ikke indlysende at idealet om nationale identiteter som rummelige og åbne for demokratisk kritik og revision svarer til den form for nationalitet der faktisk har spillet denne rolle. En måde at forstå Miller på er at han simpelthen er optimist med hensyn til muligheden for at en offentlig debat vil være inklusiv og få folk til at revidere deres forestillinger om nationen i en for ham at se ønskværdig retning, at folket via deliberativt demokrati kan "opdrages" til at blive gode, stuerene liberale nationalister. Men i så fald forudsætter han i praksis blot at pro- 
blemerne med at leve op til de modsatrettede krav vil gå væk af sig selv, og han angiver ingen konkrete vægtige grunde til at tro på denne optimisme.

\section{Konklusion}

De hidtidige kritiske overvejelser peger på et generelt problem for liberal nationalisme. Det vil være af både teoretisk og praktisk betydning hvis en fælles national identitet er en forudsætning for liberale og demokratiske velfærdsstater, og hvis politiske tiltag med henblik på at sikre at borgerne har en sådan fælles identitet, er forenelige med liberale værdier. Det er dog usikkert om en fælles national identitet både kan være udtryk for liberale værdier og være genstand for demokratisk debat på den ene side, og faktisk generere den nødvendige og stabilitetssikrende solidaritet på den anden.

Blandt de liberale der er opmærksomme på stabilitetsproblemer af den ovenfor diskuterede art, er der rimelig enighed om hvilke betingelser der skal være opfyldt for at en demokratisk velfærdsstat kan være stabil. Hvor Miller taler om solidaritet, skriver Brian Barry at der blandt borgerne skal være 1) empati, 2) respekt overfor hinanden som ligeværdige borgere, 3 ) villighed til at ofre sig for det fælles bedste, og 4) forventninger til hinanden om tilsvarende offervillighed (Barry, 2001: 79f., jf. 1983). Det interessante er at Barry derpå simpelthen definerer fælles nationalitet i den relevante forstand som tilstedeværelsen af dette sæt af holdninger i en gruppe. Ud fra denne stipulation er der automatisk tale om en fælles national identitet $\mathrm{i}$ den for liberal nationalisme relevante forstand hvis borgeme $\mathrm{i}$ en stat har de nævnte holdninger, lige gyldigt hvordan disse er tilvejebragt, dvs. lige gyldigt hvad der nærmere bestemt genererer og opretholder dem. ${ }^{11}$ Det i denne artikels sammenhæng interessante er at der ikke er nogen garanti for at personer der har de næunte holdninger over for hinanden, har en fælles national identitet $i$ Millers forstand. Andrew Mason er således enig i at noget lig de nævnte betingelser skal være opfyldte for at en liberal velfærdsstat skal være stabil, men hævder samtidig at dette ikke er det samme som en fælles national identitet. Han mener i stedet at stabilitet kan sikres hvis borgerne har "a sense of belonging to the polity" (Mason, 2000: kap. 5).

Problemet i Millers bud på hvad der kan indfri de formelle krav som en fælles identitet skal leve op til, er dels at det ikke opfylder kravene samtidig, og dels at begrebet om nationen derfor ændrer betydning undervejs i argumentationen og i så fald følger konklusionen ikke. En altemativ strategi er at forblive på det rent formelle niveau som Barry gør. Så består muligheden blot at en fælles identitet der måtte opfylde kravene, ikke vil være national i nogen genkendelig forstand. Hvis dette er tilfældet, er der ikke længere nogen særlig grund til at kalde synspunktet for liberal nationalisme. Problemerne kunne alternativt tolkes som udtryk for at spørgsmålet om stabilitet $\mathrm{i}$ liberale samfund slet ikke bør håndteres inden for en identitetsramme. Dette kan enten betyde at identitetsbegrebet helt bør droppes, eller at Miller $\mathrm{g} ø \mathrm{r}$ ret $\mathrm{i}$ at underordne den fælles identitet under det deliberative ideal, men blot ikke har taget dette skridt fuldt ud. I begge tilfælde er der brug for yderligere undersøgelser af hvad der i så fald holder samfund sammen - empiriske spørgsmål som denne artikel ikke kan give bud på. 


\section{Noter}

1. Jeg skylder to anonyme reviewers tak for konstruktiv kritik der har forbedret artiklen.

2. Miller bruger ikke selv betegnelsen liberal nationalisme, men både Kymlicka (2002: 274) og Mason (2000: 116) karakteriserer hans position på denne måde. Miller understreger dog flere steder at det han kalder "the principle of nationality" er foreneligt med liberalisme (1995: 153, 188, 192-195). Det skal bemærkes at liberal nationalisme som diskuteret her er formuleret som et teoretisk synspunkt der ikke nødvendigvis svarer fuldt ud til synspunkter (hos Bentham, Mill, von Humbolt, Mazzini, jf. Özkirimli, 2000: 39f., 107ff.) der historisk har været betegnet på samme måde, eller til dansk romantisk nationalliberalisme.

3. "Socialliberalisme" dækker til dels det Miller (1988-89) kalder"socialisme", dvs. en moderniseret, markedsorienteret socialdemokratisme.

4. Værditeoretisk kan man skelne mellem instrumentel og non-instrumentel (nogle gange kaldet intrinsisk) værdi (se Mason 2000: 42ff.). Ifølge liberal nationalisme har en fælles national identitet udelukkende instrumentel værdi, dvs. værdi som middel til at opnå et andet værdifuldt mål (her solidaritet). En anden sondring er mellem nødvendige og tilstrækkelige betingelser. At en fælles national identitet er et middel til at opnå andre, i sig selv værdifulde politiske mål, kan enten forstås således at den er en nødvendig betingelse (dvs. at målet ikke kan nås uden en fælles national identitet), tilstrækkelig (at tilstedeværelsen af en fælles national identitet er en måde at nå målet på), eller nødvendig og tilstrækkelig (hvis en fælles national identitet er den eneste måde at opnå målet på). Millers formuleringer er ofte uklare mht. om der er tale om nødvendige eller tilstrækkelige betingelser, men argumenterne for liberal nationalisme er stærkere hvis der er tale om nødvendige betingelser.

5. Miller har også en anden argumentationsstrategi med udgangspunkt i en modsætning mellem såkaldt "etisk universalisme"og "etisk partikularisme" (Miller, 1988, 1995: kap. 3). Der er flere grunde til at jeg ikke kommer ind herpå: 1) Der er tale om en etisk frem for direkte politisk diskussion, 2) Miller opstiller modsætningen, men begrunder ikke antagelsen af "etisk partikularisme", der endvidere 3) ikke nødvendigvis begrunder nationalisme, og 4) formentlig ikke er forenelig med liberalisme.

6. At have en "sense of justice" er en del af Rawls' begreb om at være en fri og lige borger (jf. 1971: 505, 1993: 19, 79, 81). Ideen om et velordnet samfund introduceres i Rawls (1971: 4ff., 453f.).

7. Canovan (1996: kap. 3) argumenterer for at en fælles nationalitet er en forudsætning for enhver form for demokrati, da "folkestyre" forudsætter en afgrænsning af "folket". Se Calhoun (1995, kap. 8) for en mere nuanceret diskussion af sammenhængen.

8. Moore drager, inspireret af Miller, denne konklusion:"[National identity] is concerned with the identification that people have with a particular political community ... It is concerned with the institutional, structural, and constitutive principles of such a community, but not with the habits or customs or character traits that are supposed to be common to all members" (Moore, 2001: 15) $0 \mathrm{~g}$ "The desire to base nationality on objective cultural characteristics is understandable, but it is almost certainly false" (2001: 57, se også 2001: 70ff.). Mason (2000: kap. 5) mener noget tilsvarende.

9. De illiberale aspekter ved Millers nationalitetsbegreb kommer endnu tydeligere fremi hans forsøg på at basere nationalisme på såkaldt "etisk partikularisme" (Miller, 1995: kap. 3, 1988). Se note 5.

10. Det skal bemærkes at denne påstand ikke er indlysende korrekt. Ifølge nogle sociologiske teorier er det således slet ikke individers identiteter og forestillinger der binder samfundet sammen, men funktionelle og strukturelle mekanismer, for eksempel en specialiseret arbejdsdeling. Det er således muligt at social sammenhængskraft skyldes sådanne sociologiske forhold, til trods for at de involverede personer tror at andre faktorer er de afgørende. Dette er et empirisk spørgsmål jeg ikke kan komme ind på her, blot skal det bemærkes at Miller intet gør for at udelukke sådanne alternative forklaringer på social enhed.

11. Noget tilsvarende kan hævdes at gøre sig gældende for Kymlickas overvejelser om "the ties that bind" i Kymlicka (1995: kap. 9). Her påpeges behovet for en fælles identitet der kan sikre den sociale enhed og solidaritet, og denne identitet betegnes som national, men det står tilbage som et åbent spørgsmål hvad denne identitet består i, og hvordan den sikrer solidaritet. 


\section{Litteratur}

Andersen, Vibeke Nornann og Kasper Møller Hansen (2002). "Deliberativt demokrati og den nationale folkehøring om euroen", Politica, 34. årgang, nr. 1, pp. 78-97.

Anderson, Benedict (1991). Imagined Communities: Reflections on the origin and spread of nationalism, London: Verso. Revised edition (original edition 1983).

Barry, Brian (1983). "Self-Government Revisited", pp. 121-154 in David Miller and Larry Sidentop (eds.), The Nature of Political Theory, Oxford: Oxford University Press.

Barry, Brian (2001). Culture and Equality, Cambridge, MA: Polity Press.

Calhoun, Craig (1995). Critical Social Theory, Minneapolis: Blackwell.

Canovan, Margaret (1996). Nationhood and Political Theory, Cheltenham: Edward Elgar.

Cohen, Joshua (1997). "Deliberation and Democratic Legitimacy", pp. 143-155 in Robert E. Goodin and Philip Pettit (eds.), Contemporary Political Philosophy: An Anthology, Oxford: Blackwell (oprindelig 1989).

Freeman, Samuel (2000). “Deliberative Democracy: A Sympathetic Comment”, Philosophy and Public Affairs, Vol. 29, No. 4, pp. 371-418.

Habernnas, Jürgen (1996). "The European Nation-State - Its Achievements and Its Limits", pp. 281-294 in Gopal Balakrishnan (ed.), Mapping the Nation, London: Verso.

Kymlicka, Will (1995). Multicultural Citizenship, Oxford: Oxford University Press.

Kymlicka, Will (2002). Contemporary Political Philosophy, 2ndedition, Oxford: Oxford University Press.

Lægaard, Sune (2002). "Multikulturalisme og nationalisme: Forskelle og ligheder", Filosofiske Studier, Bind 22, pp. 78-101.

Markell, Patchen (2000). "Making Affect Safe for Democracy? On 'Constitutional Patriotism"', Political Theory, Vol. 28, No. 1, pp. 38-63.

Mason, Andrew (2000). Community, Solidarity and Belonging: Levels of Community and their Normative Significance, Cambridge: Cambridge University Press.

Miller, David (1988). "The Ethical Significance of Nationality", Ethics, Vol. 98, pp. 647-662.

Miller, David (1988-89). "In what Sense must Socialism be Communitarian?", Social Philosophy \& Policy, Vol. 6, No. 2, pp. 51-73.

Miller, David (1995). On Nationality, Oxford: Oxford University Press.

Miller, David (2000). Citizenship and National Identity, Cambridge: Polity Press.

Moore, Margaret (2001). The Ethics of Nationalism, Oxford: Oxford University Press.

Poulsen, Jørgen J. (1998)."Fremmede i båden! - multikulturelle problemer og multikulturel kompetence", Politica, 30. årgang, nr. 2, pp. 132-148.

Rawls, John (1971). A Theory of Justice, Oxford: Oxford University Press.

Rawls, John (1993). Political Liberalism, New York: Columbia University Press.

Özkirimli, Umut (2000). Theories of Nationalism: A critical introduction, Basingstoke: Palgrave. 